\title{
EFFECT OF DIETARY SUPPLEMENTATION WITH NANO- SELENIUM OR GLUTAMINE ON GROWTH PERFORMANCE AND CARCASS CHARACTERISTICS OF GROWING RABBITS FED DIETS CONTAINING TWO CRUDE PROTEIN LEVELS \\ Dorra,Tork M.I.*; Gihan M. El-Moghazy**;Hayam M. Abo El-Maaty*; Rana H. E. Eid ${ }^{* *}$ \\ * Department of Poultry Production, Faculty of Agriculture, Mansoura University, Egypt. \\ ** Regional Center For Food and Feed, Agricultural Research Center, Giza, Egypt.
}

\begin{abstract}
In this experiment, fifty four, 6-week-old weaned New Zealand White rabbits were used to investigate the impact of dietary supplementation with nano-selenium or glutamine on growth performance and carcass characteristics of growing rabbits fed diets containing two crude protein levels. A factorial experiment $(2 \times 3)$, being two levels of dietary crude protein (16 and $14 \%$ ) without or with organic nano-Se $(0.1 \mathrm{mg} / \mathrm{kg}$ feed) and glutamine (10 g/kg feed) were performed. Rabbits were randomly distributed into 6 equal experimental groups; each contained three equal replications. Each replicate group was housed in a separate cage and fed their respective experimental diets from 6 to 15 weeks of age. Feed and water were offered ad libitum throughout the experimental period. Apart from the effect of feed supplements, rabbits fed the normal crude protein level (16\%) achieved significantly better growth performance (final live body weight, daily weight gain, daily feed intake and feed conversion ratio) while carcass traits were not affected compared with those of rabbits fed the low crude protein level. But dietary supplements (nano-Se or glutamine) did not significantly affect criteria of growth performance or dressing-out percentage of rabbits. Dietary protein by added supplements interaction did not significantly affect traits, investigated in the present study, the whole experimental period. Based on the present results, it can concluded that the crude protein level $(14 \%)$ is inadequate for attaining normal growth of post-weaning New Zealand White rabbits. However, dietary supplementation with nano-selenium or glutamine proved to be ineffective.

Keywords: Rabbits, performance, nano - selenium, glutamine, carcass traits.
\end{abstract}

\section{INTRODUCTION}

In all livestock, the current trend is to maximize $\mathrm{N}$ retention by adjusting dietary protein level accordingly to a balanced amino acid supply and thus avoiding any $\mathrm{N}$ excess in the diet. In rabbits, about two thirds of ingested $\mathrm{N}$ is excreted (Xiccato et al., 2006) and therefore a reduction in dietary protein level may help to minimize the $\mathrm{N}$ excretion to the environment. Furthermore, this reduction may also help to control the growth of pathogenic bacteria that promote higher mortality in the post-weaning rabbits. Feeding growing rabbits on dietary protein levels less than $16 \%$ may adversely affect their growth performance during the post-weaning period. 
Application of nanotechnology in the agri-food sector potentially offers huge benefits for both consumers and manufacturers in a wide range of applications. Many of these benefits result from the ultrafine dimensions of nano-particles, which enable them to reach new locations in the body, and thus can perform their biological functions more efficiently (Kaiser, 2007). According to the recent literature, consumers are more concerned about food produced by the application of nanotechnology (Siegrist et al. 2008).

It has been reported that dietary supplementation of Se at $0.1 \mathrm{ppm}$ produced an improvement in fetal and birth weight of offspring in rabbit does but the level of $0.3 \mathrm{ppm}$ was not effective (Struklec et al, 1994). Selenium passes from the blood into the tissues and is mainly concentrated on proteins particularly selenocysteine and glutathione peroxidase in kidneys, liver, pancreas, and spleen and to a small extent in muscles, bones and brain. In addition, selenium plays another vital role in the thyroid, as a part of glutathione peroxidase (Struklec et al, 1994).

Glutamine is the most abundant amino acid in the plasma, where it functions as a non-toxic nitrogen vehicle (Carrascosa et al., 1984) and a respiratory fuel (Moreadith and Lehninger, 1984). Thus, it is not surprising that glutamine behaves as a key nutrient for rapidly dividing cells. Recent studies showed that specific nutrients such as amino acids can promote gastro-intestinal integrity (Clifford, 2006).

The objective of this study was to evaluate the effect of single addition of nano-selenium $(0.1 \mathrm{ppm})$ and glutamine $(1.0 \%)$ to diets containing two levels of crude protein (16 and 14\%) on growth performance and economical efficiency of growing rabbits.

\section{MATERIALS AND METHODS}

The experimental work of the present study was carried out at the Poultry Research Unit, Agricultural Research and Experimental Center, Faculty of Agriculture, Mansoura University.

\section{Experimental animals and management.}

Fifty four, 6 weeks old weaning New Zealand White (NZW) rabbits were used in this study. Rabbits were randomly distributed into 6 equal experimental groups; each contained three equal replications. Each replicate group was housed in a separate cage with the following dimensions $(50 \times 50 \times 45 \mathrm{~cm})$ for length, width and height, respectively. Rabbits were fed their respective experimental diets from 6 to 15 weeks of age. Feed and water were offered ad libitum throughout the experimental period. The values of live body weight and feed intake were recorded on a replicate group basis and thus daily weight gain and feed conversion were also calculated.

\section{Feed supplements}

In the present study, the organic nano-selenium and glutamine were processed and supplied by the Egyptian National Research Center. The product of organic nano-Se, tested herein, contained $5000 \mathrm{ppm}$ Se of which $2.0 \mathrm{~g}$ were added to $100 \mathrm{~kg}$ of the basal diet to contain $0.1 \mathrm{mg} \mathrm{Se} / \mathrm{kg}$, while glutamine was added at a level of $10 \mathrm{~g} / \mathrm{kg}$ feed (equivalent to $1.0 \%$ of the 
diet).

Experimental rations and design.

An experiment $(2 \times 3)$ was conducted with factorial arrangement of treatments, being two levels of dietary crude protein (16 and $14 \%$ ) without or with organic nano-Se $(0.1 \mathrm{mg} / \mathrm{kg}$ feed) and glutamine $(10 \mathrm{~g} / \mathrm{kg}$ feed). Thus, six experimental rations were formulated and used. The experimental groups of rabbits were fed their respective experimental rations in pelleted form. Two basal rations were used in this study; the first containing 16\% CP which served as a control (R1) and the second one contained 14\% (R4). The composition and calculated analysis of the basal diets are presented in Table 1 , according to NRC (1977) recommendations.

Table 1: Ingredients and chemical composition of the basal diets

\begin{tabular}{|c|c|c|}
\hline \multirow[t]{3}{*}{ Feed ingredients } & \multicolumn{2}{|c|}{ Basal diets } \\
\hline & Normal protein (control) & Low protein \\
\hline & $(16 \% \mathrm{CP})$ & $(14 \% \mathrm{CP})$ \\
\hline Yellow corn & 14 & - \\
\hline Barley & 8.0 & 25.0 \\
\hline Soybean meal & 7.0 & - \\
\hline Wheat bran & 26.2 & 40.0 \\
\hline Alfalfa hay & 40.0 & 30.0 \\
\hline Molasses & 2.0 & 2.0 \\
\hline Dicalcium phosphate & 1.2 & 1.2 \\
\hline Limestone & 1.0 & 1.2 \\
\hline Sodium chloride & 0.2 & 0.2 \\
\hline Vit. Min. Premix & 0.4 & 0.4 \\
\hline Total & 100 & 100 \\
\hline \multicolumn{3}{|c|}{ Calculated analysis (as fed, NRC, 1977) } \\
\hline Digestable energy (Kcal/kg) & 2687 & 2625 \\
\hline Crude Protein (\%) & 16.20 & 14.00 \\
\hline Crude Fiber (\%) & 13.20 & 12.96 \\
\hline Ether extract (\%) & 3.00 & 2.98 \\
\hline Calcium (\%) & 1.20 & 1.20 \\
\hline Available phosphorus (\%) & 0.45 & 0.52 \\
\hline
\end{tabular}

${ }^{*}$ Premix: Each $2 \mathrm{~kg}$ of the premix contained Vit A, 10.000000 IU; Vit $D_{3}, 2000000$ IU, Vit E, $10000 \mathrm{mg}$; Zinc, $3000 \mathrm{mg}$, Manganese, $2000 \mathrm{mg}$; Iron, $4000 \mathrm{mg}$; Copper, $1000 \mathrm{mg}$; lodine, $100 \mathrm{mg}$; Selenium, $10 \mathrm{mg}$; Cobalt, $10 \mathrm{mg}$; Sodium, $23000 \mathrm{mg}$; and Magnesium, $2000 \mathrm{mg} ; \mathrm{CaCO}_{3}$ : added to $2.0 \mathrm{~kg}$.

The control ration was supplemented with organic nano-Se and glutamine and termed R2 and R3, respectively. The low crude protein basal ration was supplemented with organic nano-Se and glutamine and termed R5 and $\mathrm{R} 6$, respectively.

\section{Growth performance parameters:}

Live body weights of the experimental rabbits were individually recorded the start of the experiment and on a weekly basis thereafter, estimated to the nearest five grams in the early morning before receiving any feed or water. Body weight gain and feed conversion ratio were also calculated on a replicate group basis. Mortality of rabbits was also monitored and recorded daily. 


\section{Carcass evaluation:}

At the end of the experimental period, three rabbits from each experimental treatment were randomly chosen and slaughtered to study carcass characteristics. Rabbits were fasted for approximately 18 hours before slaughtering, individually weighed and slaughtered according to the rules of Islamic religion. Slaughter data were immediately recorded for the individual rabbits. Skinning was carried out by removing the skin including tail and legs. Carcasses were eviscerated and the different organs (e.g. Liver, heart, kidneys, viscera and lungs) were removed and immediately weighed to the nearest gram. Absolute weights of dressed carcass and organs and dressing-out percentage were estimated.

Statistical analysis:

Statistical analysis of data was carried out using the General Linear Model Program of SAS (2000). Differences among means of treatments were identified by Duncan's Multiple Range Test (Duncan, 1955). The obtained data for productive traits of different groups of rabbits were subjected to factorial analysis of variance according to the following mathematical model: $Y_{i j k}=\mu+T_{i}+L_{j}+T_{i j}+e_{i j k}$

Where; $Y_{i j k}=$ Observation of the tested factor, $\mu=$ Overall mean, $T_{i}=$ The effect of CP level, $L_{j}=$ The effect of supplements, $T L_{i j}=$ The interaction between $\mathrm{CP}$ level and supplements and $\mathrm{e}_{\mathrm{i} j \mathrm{k}}=$ experimental random error.

\section{RESULTS AND DISCUSSION}

\section{Live body weights and weight gain of growing rabbits:}

The effects of feeding diets containing two levels of crude protein and supplemented with nano-Se or glutamine on live body weights and weight gain of growing rabbits are presented in Tables 2 and 3, and the Figure 1. No deaths of rabbits occurred during the duration of this study.

Apart from the effect of feed supplements, dietary protein level did not significantly $(P>0.05)$ affect live body weights (LBW) of rabbits up to the $10^{\text {th }}$ week of age (Table 2). However, rabbits fed the normal dietary protein level (i.e. $16 \% \mathrm{CP}$ ) achieved significantly $(\mathrm{P} \leq 0.05)$ higher LBW compared with those of rabbits fed the low protein level, irrespective of the effect of fed supplements (Table 2). Regardless of the effect of dietary protein level, addition of nano-Se or glutamine had no significant effect $(P>0.05)$ on live body weights of rabbits at different ages of the experimental period, from 6 to 15 weeks of age. Dietary protein by added supplements interaction did not significantly affect live body weight of growing rabbits throughout the whole experimental period from 6 to 15 weeks of age.

As regards the effects of dietary treatments, rabbits fed the diets containing the normal crude protein level $(16 \%)$ exhibited significantly higher $(\mathrm{P} \leq 0.05)$ body weight gain during the $8^{\text {th }}, 11^{\text {th }}, 15^{\text {th }}$ and during the entire experimental period (6-15 weeks of age), regardless of the effect of dietary supplements. Apart from the effect of dietary protein level, addition of nanoSe or glutamine had no significant effect $(P>0.05)$ on body weight gain 
(BWG) of rabbits at all age intervals and the whole experimental period, except at period from 10-11 weeks of age in which nano-se caused superior daily weight gain of rabbits compared with their control counterparts. Dietary protein by added supplements interaction did not significantly affect live body weight of growing rabbits throughout the whole experimental period, except at period from 10-11 weeks of age in which nano-se produced better daily weight gain of rabbits compared with the control group.

The lack of significant differences in LBW and BWG of rabbits fed diets supplemented with glutamine is in agreement with the results of Chamorro et al. (2010), who reported that dietary supplementation with glutamine did not affect average daily gain of growing rabbits. Also, Dokoupilova et al. (2007) noted that added dietary Se did not significantly affect BWG of growing rabbits. The present results are also in harmony with the findings of Cai et al. (2012), who observed no effect of added dietary nano-Se up to $2.0 \mathrm{mglkg}$ on body weight gain of broiler chicks during both starter and grower phases. Independently from the effect of dietary treatments, means of daily weight gain, obtained in the present study, are in harmony with those reported by Schiere (2004), who found that growth rates around 15-20 grams per day are common in rabbits reared at the tropics, even though it is possible to obtain 30-40 grams per day on very good feeds.

Table 2: Effect of dietary supplementation with Nano-Selenium or glutamine on live body weight of growing rabbits fed diets containing two crude protein levels from 6 to 15 weeks of age

\begin{tabular}{|c|c|c|c|c|c|c|c|c|c|c|}
\hline \multirow[b]{2}{*}{ Dietary treatments } & \multicolumn{10}{|c|}{ Live body weight (g) at ages (in weeks) } \\
\hline & 6 & 7 & 8 & 9 & 10 & 11 & 12 & 13 & 14 & 15 \\
\hline \multicolumn{11}{|l|}{ Crude protein $(A)$ : } \\
\hline $16 \%(\mathrm{~A} 1)$ & 746 & 830 & 945 & 1074 & 1244 & $1383^{\mathrm{a}}$ & $1590^{\mathrm{a}}$ & $1708^{\mathrm{a}}$ & $1851^{\mathrm{a}}$ & $1984^{\mathrm{a}}$ \\
\hline $14 \%(\mathrm{~A} 2)$ & 750 & 835 & 911 & 1034 & 1198 & $1317^{\mathrm{b}}$ & $1491^{\mathrm{b}}$ & $1597^{\mathrm{b}}$ & $1722^{b}$ & $1816^{b}$ \\
\hline SEM & 10.4 & 12.9 & 18.8 & 26 & 19.3 & 20 & 20.48 & 20 & 23 & 27 \\
\hline Significance & NS & NS & NS & NS & NS & * & ** & ** & ** & ** \\
\hline \multicolumn{11}{|l|}{ Supplements (B): } \\
\hline $0.0(\mathrm{~B} 1)$ & 746 & 831 & 918 & 1051 & 1220 & 1337 & 1551 & 1654 & 1795 & 1903 \\
\hline $0.1 \mathrm{Se}(\mathrm{B} 2)$ & 757 & 842 & 942 & 1056 & 1234 & 1374 & 1573 & 1688 & 1829 & 1945 \\
\hline 1.1 .0 glutamine $(\mathrm{B} 3)$ & 742 & 827 & 923 & 1055 & 1208 & 1339 & 1499 & 1614 & 1737 & 1853 \\
\hline SEM & 12.7 & 15.8 & 23 & 31.4 & 24 & 24 & 25.1 & 25 & 28 & 33 \\
\hline Significance & NS & NS & NS & NS & NS & NS & NS & NS & NS & NS \\
\hline \multicolumn{11}{|l|}{ AB Interaction: } \\
\hline $\mathrm{A} 1 \mathrm{~B} 1=\mathrm{R} 1$ & 742 & 815 & 914 & 1053 & 1203 & 1339 & 1565 & 1682 & 1843 & 1983 \\
\hline $\mathrm{A} 1 \mathrm{~B} 2=\mathrm{R} 2$ & 763 & 842 & 975 & 1080 & 1272 & 1426 & 1627 & 1745 & 1887 & 2019 \\
\hline $\mathrm{A} 1 \mathrm{~B} 3=\mathrm{R} 3$ & 734 & 835 & 945 & 1089 & 1257 & 1385 & 1579 & 1696 & 1823 & 1949 \\
\hline $\mathrm{A} 2 \mathrm{~B} 1=\mathrm{R} 4$ & 750 & 847 & 921 & 1050 & 1237 & 1336 & 1536 & 1626 & 1746 & 1824 \\
\hline $\mathrm{A} 2 \mathrm{~B} 2=\mathrm{R} 5$ & 752 & 841 & 910 & 1031 & 1196 & 1322 & 1519 & 1631 & 1770 & 1870 \\
\hline $\mathrm{A} 2 \mathrm{~B} 3=\mathrm{R} 6$ & 749 & 818 & 901 & 1020 & 1159 & 1294 & 1419 & 1533 & 1651 & 1756 \\
\hline SEM & 18.0 & 22.3 & 32 & 44.5 & 33.4 & 34 & 35.5 & 35 & 39.1 & 47 \\
\hline Significance & NS & NS & NS & NS & NS & NS & NS & NS & NS & NS \\
\hline
\end{tabular}

a-b: For each of the main effects, means within the same column with different

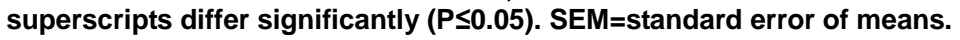


Table 3: Effect of dietary supplementation with Nano-Selenium or glutamine on daily body weight gain of growing rabbits fed diets containing two crude protein levels from 6 to 15 weeks of age

\begin{tabular}{|c|c|c|c|c|c|c|c|c|c|c|}
\hline \multirow[b]{2}{*}{\begin{tabular}{|l} 
Dietary \\
Treatments \\
\end{tabular}} & \multicolumn{10}{|c|}{ Daily weight gain (g) } \\
\hline & $\begin{array}{l}6-7 \\
\text { wk }\end{array}$ & $\begin{array}{l}7-8 \\
\text { wk }\end{array}$ & $\begin{array}{l}8-9 \\
\text { wk } \\
\end{array}$ & \begin{tabular}{|l|}
$9-10$ \\
wk
\end{tabular} & \begin{tabular}{|l|}
$10-11$ \\
wk
\end{tabular} & \begin{tabular}{|l|}
$11-12$ \\
wk
\end{tabular} & $\begin{array}{l}12-13 \\
\mathrm{wk}\end{array}$ & \begin{tabular}{|l|}
$\begin{array}{l}13-14 \\
\text { wk }\end{array}$ \\
\end{tabular} & $\begin{array}{l}14-15 \\
\text { wk }\end{array}$ & $\begin{array}{l}6-15 \\
\text { wk }\end{array}$ \\
\hline \multicolumn{11}{|l|}{ Crude protein $(A)$ : } \\
\hline $16 \%(\mathrm{~A} 1)$ & 12.0 & $16.32^{\mathrm{a}}$ & 18.46 & 24.35 & $19.84^{\mathrm{a}}$ & 29.60 & 16.78 & 20.49 & $18.94^{\mathrm{a}}$ & $19.64 a$ \\
\hline $14 \%(\mathrm{~A} 2)$ & 12.22 & $10.75^{b}$ & 17.57 & 23.40 & $17.10^{\mathrm{b}}$ & 24.84 & 15.80 & 17.97 & $13.43^{\mathrm{b}}$ & $16.93 b$ \\
\hline SEM & 1.446 & 1.207 & 1.488 & 1.382 & 0.535 & 2.903 & 0.986 & 1.823 & 1.196 & 0.404 \\
\hline Significance & NS & ** & NS & NS & ** & NS & NS & NS & ** & ** \\
\hline \multicolumn{11}{|l|}{ Supplements (B): } \\
\hline $0.0(\mathrm{~B} 1)$ & 12.12 & 12.40 & 19.10 & 24.12 & $16.71^{\mathrm{b}}$ & 30.48 & 14.79 & 20.12 & 15.50 & 18.37 \\
\hline $0.1 \mathrm{Se}(\mathrm{B} 2)$ & 12.05 & 14.40 & 16.19 & 25.52 & $19.98^{\mathrm{a}}$ & 28.43 & 16.45 & 20.02 & 16.57 & 18.85 \\
\hline 1. 1.0 glutamine $(\mathrm{B} 3)$ & 12.17 & 13.79 & 18.76 & 21.98 & $18.71^{\mathrm{ab}}$ & 22.76 & 16.52 & 17.55 & 16.48 & 17.64 \\
\hline EM & 1.771 & 1.478 & 1.823 & 1.692 & 0.655 & 3.555 & 1.208 & 2.232 & 1.465 & 0.495 \\
\hline Significance & NS & NS & NS & NS & * & NS & NS & NS & NS & NS \\
\hline \multicolumn{11}{|l|}{$A B$ Interaction: } \\
\hline $\mathrm{A} 1 \mathrm{~B} 1=\mathrm{R} 1$ & 10.33 & 14.24 & 19.81 & 21.48 & 19.33 & 32.38 & 16.71 & 23.00 & 19.91 & 19.96 \\
\hline $\mathrm{A} 1 \mathrm{~B} 2=\mathrm{R} 2$ & 11.29 & 19.0 & 15.05 & 27.48 & 22.00 & 28.71 & 16.86 & 20.29 & 18.86 & 19.95 \\
\hline $\mathrm{A} 1 \mathrm{~B} 3=\mathrm{R} 3$ & 14.38 & 15.71 & 20.52 & 24.10 & 19.18 & 27.71 & 16.71 & 18.19 & 18.05 & 19.29 \\
\hline $\mathrm{A} 2 \mathrm{~B} 1=\mathrm{R} 4$ & 13.91 & 10.57 & 18.38 & 26.76 & 14.10 & 28.57 & 12.86 & 17.24 & 11.10 & 17.05 \\
\hline $\mathrm{A} 2 \mathrm{~B} 2=\mathrm{R} 5$ & 12.81 & 9.81 & 17.33 & 23.57 & 17.95 & 28.14 & 16.05 & 19.76 & 14.29 & 17.75 \\
\hline $\mathrm{A} 2 \mathrm{~B} 3=\mathrm{R} 6$ & 9.95 & 11.86 & 17.00 & 19.86 & 19.24 & 17.81 & 16.33 & 16.91 & 14.91 & 15.98 \\
\hline SEM & 2.504 & 2.090 & 2.578 & 2.393 & 0.926 & 5.027 & 0.505 & 3.157 & 2.072 & 0.699 \\
\hline Significance & NS & NS & NS & NS & & NS & NS & NS & NS & NS \\
\hline
\end{tabular}

a-b: For each of the main effects, means within the same column with different superscripts differ significantly $(P \leq 0.05)$. SEM=standard error of means.

In disagreement with the present results, Ebeid et al. (2012) reported that feeding male California rabbits on diets supplemented with organic Se $(0.15$ or $0.30 \mathrm{ppm})$ resulted in an increase in live body weight and daily weight gain compared with their control counterparts. Similarly, Malayoglu et al. (2009) fed broiler chicks from day-old to 42 days of age on diets supplemented with organic Se (Se-enriched yeast) at 0.15 or $0.30 \mathrm{mglkg}$ and found a significant improvement in body weight and body weight gain due to feeding the organic Se at $0.30 \mathrm{mglkg}$ diet but not at the level of $0.15 \mathrm{mglkg}$. Working with growing pullets, Mohapatra et al. (2014) found that feeding diets enriched with nano-Se up to $0.30 \mathrm{mglkg}$ from 9 to 20 weeks of age produced an improvement in live body weight of pullets when the level of added nanoSe reached $0.60 \mathrm{mglkg}$ body weight of pullets was negatively affected. In addition, Hanafy et al. (2009) evaluated the response of Bandarah laying hens to feeding diets fortified with organic Se up to $0.30 \mathrm{mglkg}$ from 40 to 60 weeks of age and found that live body weight of hens increased significantly compared with the control group.

\section{Feed intake and feed conversion ratio of growing rabbits:}

The effects of feeding diets containing two levels of crude protein and supplemented with nano-Se or glutamine on daily feed intake (DFI) and feed conversion ratio (FCR) of growing rabbits are presented in Tables 4 and 5 , respectively. Apart from the effect of feed supplements, dietary protein level exerted a significant effect $(P \leq 0.05)$ on DFI of rabbits during the periods of 9 - 
$10,10-11,11-12,12-13,13-14,14-15$ weeks of age (Table 4). During the entire experimental period (from 6 to 15 weeks of age) DFI of rabbits fed the low crude protein diet was significantly lower $(\mathrm{P}<0.01)$ than that of the control group, irrespective of the effect of added supplements (Table 4).

With regard to the effect of dietary protein level on FCR, dietary protein level had a significant effect $(P \leq 0.05)$ on $F C R$ of growing rabbits during the periods of $7-8$ and $10-11$ weeks of age and during the whole experimental period (Table 5), irrespective of the effect of dietary supplements. During the entire experimental period, FCR of rabbits fed the normal crude protein level $(16 \%)$ was significantly better $(P<0.05)$ than that of rabbits fed the low crude protein level (14\%), regardless of the effect of added supplements (Table 5).

Table 4: Effect of dietary supplementation with nano-selenium or glutamine on daily feed intake of growing rabbits fed diets containing two crude protein levels from 6 to 15 weeks of age

\begin{tabular}{|c|c|c|c|c|c|c|c|c|c|c|}
\hline \multirow[b]{2}{*}{$\begin{array}{l}\text { Dietary } \\
\text { treatments }\end{array}$} & \multicolumn{10}{|c|}{ Daily feed intake (g) } \\
\hline & $\begin{array}{l}6-7 \\
\text { wk }\end{array}$ & $\begin{array}{l}7-8 \\
\text { wk }\end{array}$ & $\begin{array}{l}8-9 \\
\text { wk }\end{array}$ & $\begin{array}{l}9-10 \\
\text { wk }\end{array}$ & $\begin{array}{l}10-11 \\
\text { wk }\end{array}$ & \begin{tabular}{|l|}
$11-12$ \\
wk
\end{tabular} & $\begin{array}{c}12-13 \\
\text { wk }\end{array}$ & \begin{tabular}{|l|}
$13-14$ \\
wk
\end{tabular} & $\begin{array}{l}14-15 \\
\text { wk }\end{array}$ & $\begin{array}{l}6-15 \\
\text { wk }\end{array}$ \\
\hline \multicolumn{11}{|l|}{ Crude protein $(\mathrm{A})$ : } \\
\hline $16 \%(\mathrm{~A} 1)$ & 5.39 & 50.48 & 62.22 & $71.57^{\mathrm{a}}$ & $73.26^{b}$ & $111.44^{\mathrm{a}}$ & $103.17^{\mathrm{a}}$ & $104.62^{\mathrm{a}}$ & $110.77^{a}$ & $81.43^{a}$ \\
\hline $14 \%(\mathrm{~A} 2)$ & 45.88 & 48.60 & 60.12 & $68.30^{\mathrm{b}}$ & $83.30^{\mathrm{a}}$ & $105.67^{b}$ & $92.06^{\mathrm{b}}$ & $93.94^{\mathrm{b}}$ & $94.36^{b}$ & $76.91^{\mathrm{b}}$ \\
\hline SEM & 0.633 & 0.702 & 0.737 & 0.724 & 2.733 & 1.027 & 2.565 & 2.580 & 3.547 & 0.443 \\
\hline Significance & NS & NS & NS & * & * & $* *$ & * & * & $* *$ & ** \\
\hline \multicolumn{11}{|l|}{ Supplements (B): } \\
\hline 0.0 (B1) & 44.5 & 48.73 & 59.57 & 69.37 & 80.77 & 109.17 & 95.78 & 100.60 & 102.15 & 78.96 \\
\hline $0.1 \mathrm{Se}(\mathrm{B} 2)$ & 47.08 & 51.45 & 61.55 & 71.50 & 71.02 & 109.83 & 99.77 & 101.0 & 104.65 & 79.76 \\
\hline 1.1.0glutamine (B3) & 45.32 & 48.43 & 62.40 & 68.93 & 83.05 & 106.67 & 97.28 & 96.25 & 100.88 & 78.80 \\
\hline SEM & 0.775 & 0.860 & 0.903 & 0.887 & 3.347 & 1.258 & 3.141 & 3.160 & 4.344 & 0.543 \\
\hline Significance & NS & NS & NS & NS & NS & NS & NS & NS & NS & NS \\
\hline \multicolumn{11}{|l|}{ AB Interaction: } \\
\hline $\mathrm{A} 1 \mathrm{~B} 1=\mathrm{R} 1$ & 4.67 & 49.27 & 59.87 & 70.10 & 68.93 & 112.33 & 102.90 & 104.83 & 112.67 & 80.62 \\
\hline $\mathrm{A} 1 \mathrm{~B} 2=\mathrm{R} 2$ & 46.53 & 52.40 & 62.73 & 72.73 & 69.43 & 110.00 & 108.33 & 111.67 & 114.87 & 83.19 \\
\hline $\mathrm{A} 1 \mathrm{~B} 3=\mathrm{R} 3$ & 44.97 & 49.77 & 64.07 & 71.87 & 81.40 & 112.00 & 98.27 & 97.37 & 104.77 & 80.50 \\
\hline $\mathrm{A} 2 \mathrm{~B} 1=\mathrm{R} 4$ & 44.33 & 48.20 & 59.27 & 68.63 & 92.60 & 106.00 & 88.67 & 96.37 & 91.63 & 77.30 \\
\hline $\mathrm{A} 2 \mathrm{~B} 2$ = R5 & 47.63 & 50.50 & 60.37 & 70.27 & 72.60 & 109.67 & 91.20 & 90.33 & 94.43 & 76.33 \\
\hline A2B3 = R6 & 45.67 & 47.10 & 60.73 & 66.00 & 84.7 & 101.33 & 96.30 & 95.13 & 97.00 & 77.11 \\
\hline SEM & 1.096 & 1.216 & 1.277 & 1.254 & 4.734 & 1.780 & 4.442 & 4.468 & 6.143 & 0.768 \\
\hline Significance & NS & NS & NS & NS & NS & * & NS & NS & NS & NS \\
\hline
\end{tabular}

a-b: For each of the main effects, means within the same column with different superscripts differ significantly $(\mathrm{P} \leq 0.05)$. SEM=standard error of means.

Regardless of the effect of dietary protein level, addition of nano-Se or glutamine had no significant effect $(P>0.05)$ on DFI or FCR of rabbits throughout the experimental period, except during the period of 10-11 weeks of age in which rabbits fed the nano-Se-supplemented diets exhibited significantly better $(\mathrm{P}<0.01)$ FCR compared with that of the control group. Dietary protein by added supplements interaction did not significantly affect DFI and FCR of growing rabbits throughout the whole experimental period from 6 to 15 weeks of age. 
Table 5: Effect of dietary supplementation with Nano-Selenium or glutamine on feed conversion ratio of growing rabbits fed diets containing two crude protein levels from 6 to 15 weeks of age

\begin{tabular}{|c|c|c|c|c|c|c|c|c|c|c|}
\hline \multirow[b]{2}{*}{\begin{tabular}{|l} 
Dietary \\
treatments
\end{tabular}} & \multicolumn{10}{|c|}{ Feed conversion ratio ( g feed: g gain) } \\
\hline & $\begin{array}{l}6-7 \\
\text { wk }\end{array}$ & $\begin{array}{l}7-8 \\
\text { wk }\end{array}$ & $\begin{array}{l}8-9 \\
\text { wk }\end{array}$ & $\begin{array}{l}9-10 \\
\text { wk }\end{array}$ & $\begin{array}{c}10-11 \\
\text { wk }\end{array}$ & $\begin{array}{c}11-12 \\
\text { wk }\end{array}$ & $\begin{array}{c}12-13 \\
\text { wk }\end{array}$ & $\begin{array}{c}13-14 \\
\text { wk }\end{array}$ & $\begin{array}{c}14-15 \\
\text { wk }\end{array}$ & $\begin{array}{l}\text { 6-15 } \\
\text { wk }\end{array}$ \\
\hline \multicolumn{11}{|l|}{ Crude protein $(\mathrm{A})$ : } \\
\hline $16 \%(\mathrm{~A} 1)$ & 4.42 & $3.27^{\mathrm{b}}$ & 3.70 & 3.07 & $3.73^{\mathrm{b}}$ & 4.13 & 6.28 & 5.58 & 6.03 & $4.16^{\mathrm{b}}$ \\
\hline $14 \%(\mathrm{~A} 2)$ & 4.15 & $4.80^{\mathrm{a}}$ & 3.48 & 2.98 & $5.06^{a}$ & 5.55 & 6.29 & 5.42 & 7.29 & $4.57^{\mathrm{a}}$ \\
\hline SEM & 0.651 & 0.363 & 0.330 & 0.206 & 0.233 & 1.188 & 0.398 & 0.576 & 0.443 & 1.05 \\
\hline Significance & NS & * & NS & NS & ** & NS & NS & NS & NS & $*$ \\
\hline \multicolumn{11}{|l|}{ Supplements (B): } \\
\hline $0.0(\mathrm{~B} 1)$ & 3.79 & 4.29 & 3.34 & 3.01 & $5.15^{\mathrm{a}}$ & 3.67 & 6.57 & 5.33 & 7.02 & 4.32 \\
\hline $0.1 \mathrm{Se}(\mathrm{B} 2)$ & 4.15 & 4.01 & 4.05 & 2.89 & $3.61^{\mathrm{b}}$ & 3.99 & 6.26 & 5.46 & 6.79 & 4.25 \\
\hline \begin{tabular}{|ll}
$\begin{array}{l}1 . \\
\text { (B3) }\end{array}$ & glutamine \\
\end{tabular} & 4.90 & 3.81 & 3.37 & 3.19 & $4.43^{\mathrm{ab}}$ & 6.85 & 6.03 & 5.70 & 6.17 & 4.52 \\
\hline SEM & 0.798 & 0.445 & 0.405 & 0.252 & 0.285 & 1.455 & 0.488 & 0.705 & 0.542 & 0.129 \\
\hline Significance & NS & NS & NS & NS & $\star \star \star *$ & NS & NS & NS & NS & NS \\
\hline AB Interaction: & & & & & & & & & & \\
\hline $\mathrm{A} 1 \mathrm{~B} 1=\mathrm{R} 1$ & 4.89 & 3.73 & 3.35 & 3.43 & 3.58 & 3.62 & 6.20 & 4.99 & 5.67 & 4.03 \\
\hline$=\mathrm{R} 2$ & 4.46 & 2.84 & 4.61 & 2.78 & 3.16 & 4.09 & 6.59 & 6.34 & 6.59 & 4.17 \\
\hline & 4.40 & 3.24 & 3.14 & 3.01 & 4.46 & 4.68 & 6.07 & 5.39 & 5.82 & 4.18 \\
\hline $\mathrm{A} 2 \mathrm{~B} 1=\mathrm{R} 4$ & 3.20 & 4.84 & 3.34 & 2.58 & 6.71 & 3.72 & 6.94 & 5.65 & 8.39 & 4.54 \\
\hline $\mathrm{A} 2 \mathrm{~B} 2=\mathrm{R} 5$ & 3.84 & 5.19 & 3.49 & 3.00 & 4.07 & 3.90 & 5.94 & 4.58 & 6.99 & 4.31 \\
\hline $\mathrm{A} 2 \mathrm{~B} 3=\mathrm{R} 6$ & 5.40 & 4.37 & 3.61 & 3.37 & 4.40 & 9.01 & 5.99 & 6.01 & 6.51 & 4.83 \\
\hline SEM & 1.128 & 0.629 & 0.572 & 0.356 & 0.403 & 2.058 & 0.690 & 0.997 & 0.767 & 0.182 \\
\hline Significance & NS & NS & NS & NS & $* *$ & NS & NS & NS & NS & NS \\
\hline
\end{tabular}

a-b: For each of the main effects, means within the same column with different superscripts differ significantly $(P \leq 0.05)$. SEM=standard error of means.

The interaction between dietary protein level and added supplements on DFI of growing rabbits was insignificant, except during the period of 11-12 weeks of age which was significant $(P<0.05)$. Dietary protein by added supplements interaction did not significantly affect FCR of growing rabbits, except during the period of 10-11 weeks of age which was significant $(\mathrm{P}<0.01)$.

The present results are in agreement with the findings reported by Chamorro et al. (2007), who found that dietary supplementation with glutamine did not affect average daily feed intake or feed efficiency of growing rabbits during the entire fattening period. Also, Dokoupilova et al. (2007) noted that added Se (Se-enriched yeast) did not affect FCR of growing rabbits. The present results also agree with the findings of Cai et al. (2012), who observed no effect of added dietary nano-Se up to $2.0 \mathrm{mglkg}$ on feed intake of broiler chicks during both starter and grower phases. Similar results were obtained by Malayoglu et al. (2009), who found that broiler chicks fed diets supplemented with organic Se (Se-enriched yeast) at 0.15 or $0.30 \mathrm{mglkg}$ achieved comparable means of feed intake and feed conversion ratio to those of the control chicks. With laying hens, Hanafy et al. (2009) observed no significant differences in feed intake of Bandarah pullets fed diets fortified with organic Se up to $0.30 \mathrm{mglkg}$ compared with the control group. 
On the other hand, Ebeid et al. (2012) reported that feeding male California rabbits on diets supplemented with organic Se $(0.15$ or $0.30 \mathrm{ppm})$ led to inferior feed conversion ratios compared with their control counterparts. Working with growing pullets, Mohapatra et al. (2014) found that feeding diets enriched with nano-Se up to $0.30 \mathrm{mg} / \mathrm{kg}$ from 9 to 20 weeks of age positively affected feed conversion ratio of pullets but when the level of added nano-Se reached $0.60 \mathrm{mg} / \mathrm{kg} \mathrm{FCR}$ was negatively affected. In general, the inconsistent results among different studies in the scientific literature regarding the responsiveness of growing animals to dietary supplementation with nanoselenium or glutamine could be related to a variety of factors such as species, genotype, age, diet composition (amino acid profile), duration of study, processing of nano-Se and its carrier, and added dose etc.

\section{Carcass characteristics of growing rabbits:}

The effects of feeding diets containing two levels of crude protein and supplemented with nano-Se or glutamine on carcass characteristics of growing rabbits are presented in Table 6.

Apart from the effect of feed supplements, dietary protein level exerted a significant effect $(P \leq 0.05)$ on absolute weights of skin, head, liver and kidneys but other carcass traits were not affected (Table 6). Apart from the effect of feed supplements, feeding the low crude protein level $(14 \%)$ negatively affected $(P \leq 0.05)$ weights of skin, head and kidneys of rabbits compared with those of the control group. Regardless of the effect of dietary protein level, addition of glutamine led to a significant reduction in weights of skin, viscera, head, liver and kidneys but added nano-Se had no effect on all carcass traits measured compared with the control group. Dietary protein by added supplements interaction did not significantly affect all carcass traits examined in of 15-week-old growing rabbits.

The absence of significant differences in dressing-out percentage of the experimental rabbits agrees with the findings of Dokoupilova et al. (2007), who noted that added Se (Se-enriched yeast) did not affect dressing-out percentage of growing rabbits. In disagreement with the present results, Ebeid et al. (2012) reported that feeding male California rabbits on diets supplemented with organic Se $(0.15$ or $0.30 \mathrm{ppm})$ led to an improvement in both hot carcass weight and dressing percentage compared with their control counterparts. 
Dorra,Tork M.I. et al. 
Fig (1)

The effect of nano-selenium or glutamine

supplementation on the average daily gain $(\mathrm{g} / \mathrm{h} / \mathrm{d})$

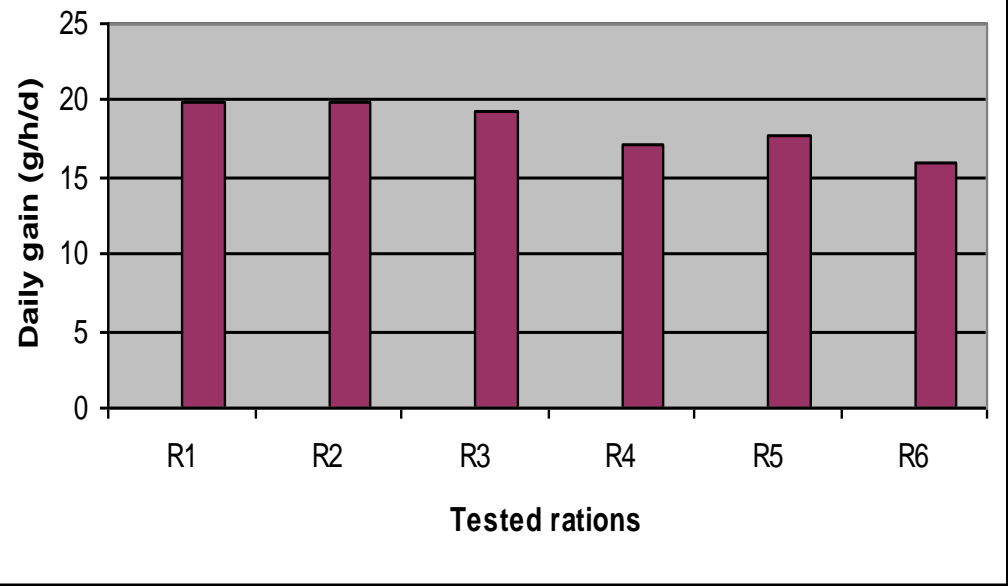

Fig (2)

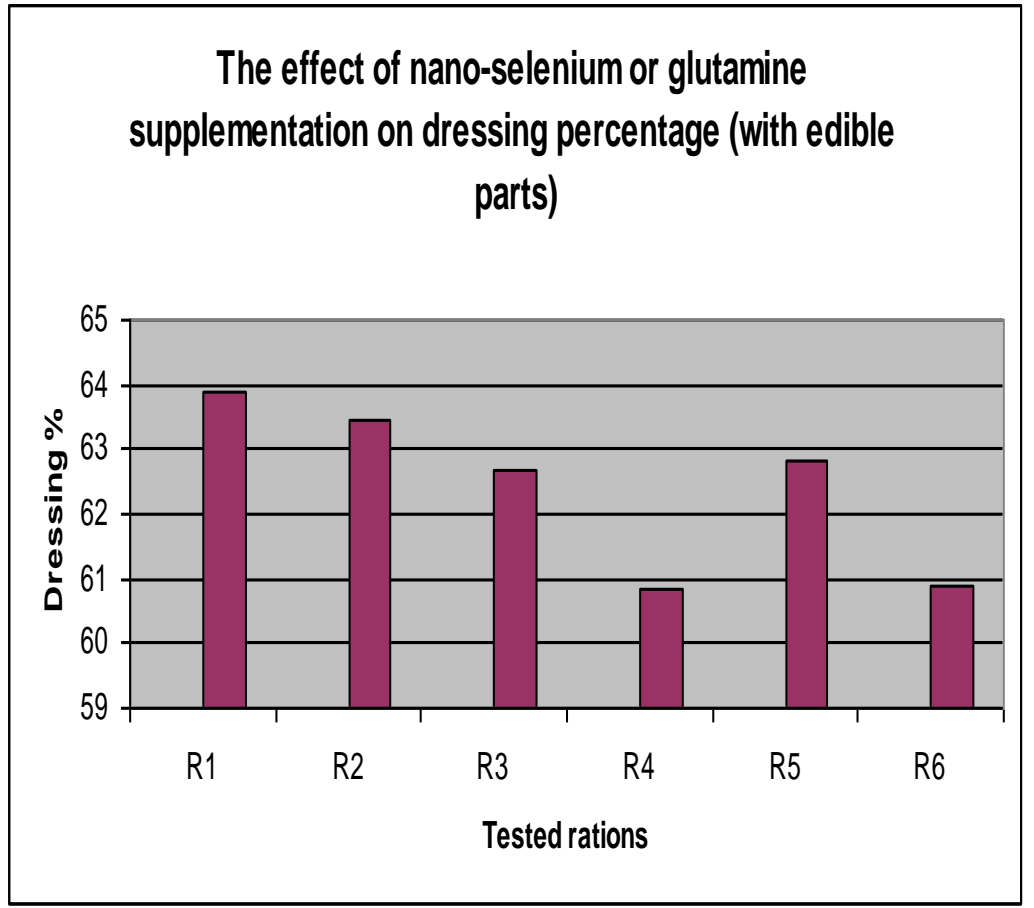




\section{REFERENCES}

Black, J.L. (2001). Quality feed grains - research highlights opportunities. Proceedings of the $10^{\text {th }}$ ausralian barley Technical symposium. http: // www. Regional.org. au/abts/2001/m3/black.htm retrieved $19^{\text {th }}$ oct 2006 .

Cai, S.J.; C.X. Wu; L.M. Gong; T.Song; H. Wu and L.Y. Zhang (2012). Effects of nano-selenium on performance, meat quality, immune function, oxidation resistance, and tissue selenium content in broilers. Poultry Sci., 91: 2532-2539.

Carrascosa , J. M. , Martine , P. and Nune , de castro , I. (1984). Nitrogen movement between host and tumor in mice inoculated with Ehrlich ascetic tumor cells. Cancer Res., $44: 3831$.

Chamorro, S; C. de Blas; G. Grant; I. Badiola; D. Menoyo and R.Carabano.(2010). Effect of dietary supplementation with glutamine and a combination of glutamine-arginine on intestinal health in twentyfive-day-old weaned rabbits. J.Anim. Sci. 88:170-180.

Clifford , A. (2006). Nutritional - based health in animal production . Nutr. Res. Rev. 19:79.

De Blas , C. and Wiseman , J. (2003) . The Nutrition of the Rabbit , CABI publishing, Oxon .

Dokoupilova, A.; M. Marounek; V. Skřivanová; P. Březina (2007). Selenium content in tissues and meat quality in rabbits fed selenium yeast. Czech J. Anim. Sci., 52 (6):165-169.

Duncan, D. B. (1955). Multiple Range and Multiple F Test. Biometrics, 11: 1 24.

Ebeid, T.; H. Zeweil; M. Basyony and H. Badry (2012). The impact of incorporation of organic selenium into meat on growth performance, antioxidative status, and immue response in growing rabbits. In: Proc. Of the $10^{\text {th }}$ World Rabbit Congress, September 3-6, Sharm El-Sheikh, Egypt, pp. 861-864.

Hanafy, Maysa M.; A.M. H. El-Sheikh and E.A. Abdalla (2009). The effect of organic selenium supplementation on productive and physiological performance in local strain of chicken. 1. The effect of organic selenium (SeL-Plex TM on productive reproductive and physiological traits of Bandarah local strain. Egyption Poultry Sci., 29 (4): 1061-1084.

Jenkins, J.R. (1999). Feeding Recommendations for the house Rabbit. Veterinary clinics of North America : Exotic Animal practice. Vol. 2 P. 143. W.B. Saunders company, Philadelphia .

Kaiser, H. (2007) Nanotechnology in food, food processing. Agriculture , packaging and consumption. State of science, Technologies, Markets , Application and Developments to 2015 and 2040.

Lebas, F. and Colin , M. (1992) . World rabbit production and research : Situation in 1992. Fifth world rabbit congress, Vol. A, P.29. 
Malayoglu, H.B.; S.Ozkan; S. Kocturk; G. Oklay and M. Ergul (2009). Dietary vitmin $E$ ( $\alpha$-tocopheryl acetate) and formance anantioxidant status of broilers fedn-3 PUFA- enriched feeds. South African J. Anim. Sci., 39(4): 274-285.

Mohapatra, P.; R.K. Swain; S.K. Mishra; T. Behera; P. Swain; N.C. Behura; G. Sahoo; K. Sethy; B.P. Bhol and K. Dhama (2014). Effects of nanoselenium Supplementation on the performance of layer grower birds. Asian J. Anim. Vet. Adv., 9(10): 641-652.

Moreadith , R.w. and Lehninger, A.L. (1984). The pathways of glutamate and glutamine oxidation by tumor cell mitochondria . J. Biol chem., 259 : 6215.

NRC (National Research Council) (1977). Nutrient requirements of domestic animals, No.9. Nutrient requirements of rabbits. Second Revised Ed. National Academy of science - National Research Council , Washington, DC, USA.

Samkol, P., preston, T.R. and Ly, J. (2006). Effect of increasing offer level of water spainach (Ipomoea aquatica) on intake, growth and digestibility coefficients of rabbits. livestock research for Rural development. Volum 18, Article\#25. Retrieved|March|7.|(2006), |from http://www.cipav.org.co/lrrd/Irrd18/2/samk18025.htm.

Santagreu, M.A. (1992). Estimation de los parametros geneticos de la taxa de ovulacion, supervivencia prenatal y tamano de camade en conejo. Ph.D. thesis, univ. of Valencia, Spain .

SAS (2000). Statistical Analysis System / STAT User's Guide, release 6.03. Ed., SAS Institute . Inc., Cary, Nc. USA, PP. 125.

Schiere , J.B. (2004). Backyard rabbit farming in the tropics Agromisa foundation, Wageningen.

Siegrist , M. , Stampfli , N. , Kastenhol3 , H. and Keller , C. (2008). Perceived risks and perceived benefits of different nanotechnology foods and nanotechnology food packaging. Appetite, 51 (2) , 283.

Strucklec, M. , Dermelj, M. , Stibilij , v. and Rajh , I . (1994). The effect of selenium added to feed stuffs on its content in tissues and on growth of rabbits . Krmiva, $36: 117$.

Xiccato , G., Trocino , A., and Nicodemus , N. ( 2006). Nutrition of the young and growing rabbit: a comparative approach with the doe. In: Maertens , L., Coudert, P. (ed) Recent advances in rabbit science. IIVO, Merelbeke, Belgium, 239. 
تأثير إضافة النانو سلينيوم أو الجلوتامين على الأداء الانتاجى وخصائص الأبيحة

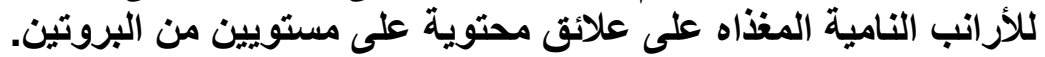

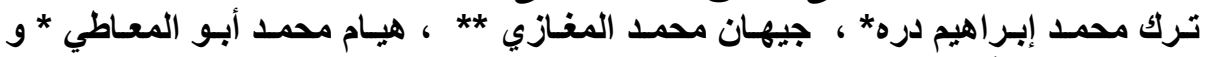

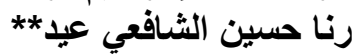

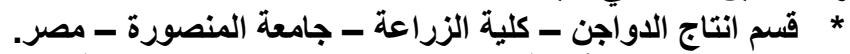

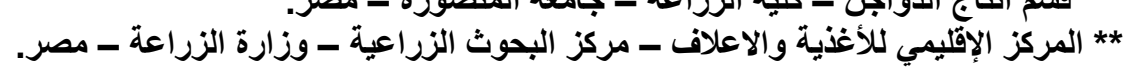

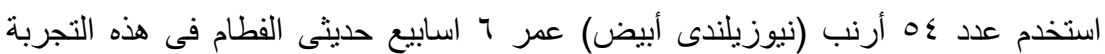

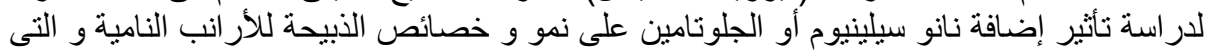

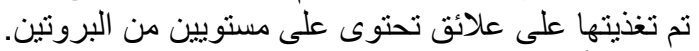

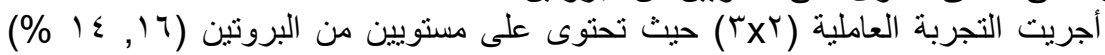

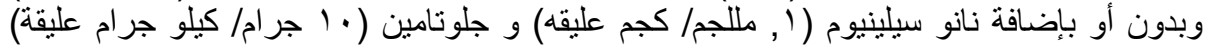

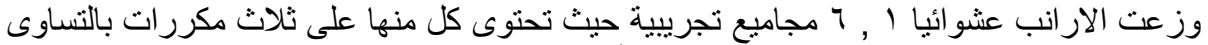

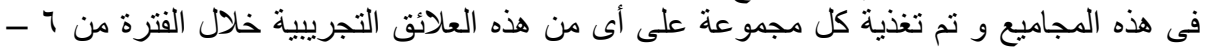

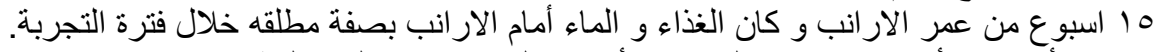

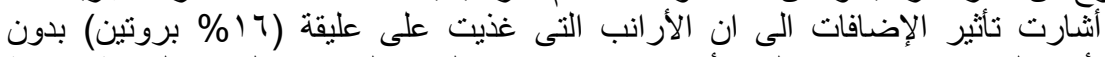

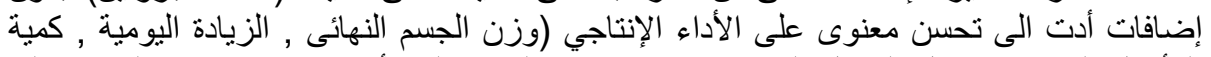

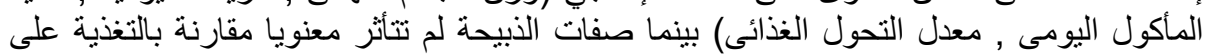

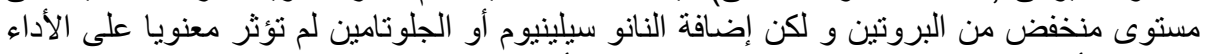

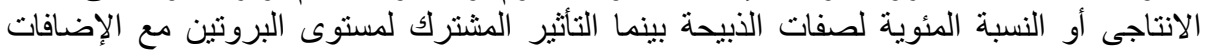

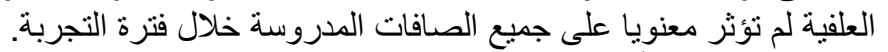

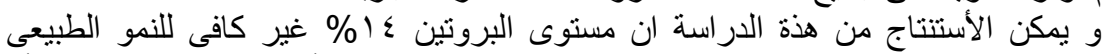

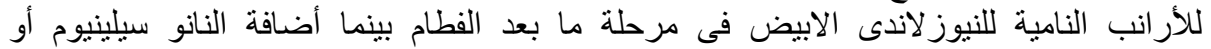

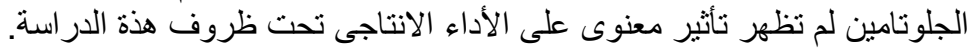


J. Animal and Poultry Prod., Mansoura Univ., Vol. 5 (9), September, 2014 



\section{J. Animal and Poultry Prod., Mansoura Univ., Vol. 5 (9): 549-562, 2014}

Table 6: Effect of dietary supplementation with Nano-Selenium or glutamine on some carcass characteristics of 15-week-old growing rabbits fed diets containing two crude protein levels

\begin{tabular}{|c|c|c|c|c|c|c|c|c|c|c|}
\hline $\begin{array}{l}\text { Dietary } \\
\text { treatments }\end{array}$ & $\begin{array}{l}\text { LBW } \\
\text { (g) }\end{array}$ & $\begin{array}{c}\text { Dressing } \\
(\%)\end{array}$ & $\begin{array}{c}\text { Skin wt. } \\
\text { (g) }\end{array}$ & $\begin{array}{l}\text { Lungs } \\
\text { wt. (g) }\end{array}$ & $\begin{array}{l}\begin{array}{l}\text { Viscera } \\
\text { wt. (g) }\end{array} \\
\end{array}$ & $\begin{array}{l}\text { Head } \\
\text { wt. (g) }\end{array}$ & $\begin{array}{l}\text { Liver } \\
\text { wt. (g) }\end{array}$ & $\begin{array}{l}\text { Heart } \\
\text { wt.(g) }\end{array}$ & $\begin{array}{c}\text { Kidneys } \\
\text { wt. (g) }\end{array}$ & $\begin{array}{c}\text { Total } \\
\text { dressing (\%) } \\
\end{array}$ \\
\hline \multicolumn{11}{|l|}{ Crude protein $(A)$ : } \\
\hline $16 \%$ (A1) & $2212^{\mathrm{a}}$ & 58.31 & $379^{a}$ & 15.89 & 333 & $112.0^{\mathrm{a}}$ & $86.1^{a}$ & 8.33 & $17.6^{\mathrm{a}}$ & 61.51 \\
\hline $14 \%(\mathrm{~A} 2)$ & $1970^{b}$ & 57.26 & $338^{b}$ & 12.89 & 317 & $84.4^{\mathrm{b}}$ & $65.6^{\mathrm{b}}$ & 6.33 & $12.6^{\mathrm{b}}$ & 63.36 \\
\hline SEM & 33.2 & 0.79 & 8 & 1.111 & 11 & 6.59 & 5.08 & 0.97 & 1.14 & 0.76 \\
\hline Significance & ** & NS & ** & NS & NS & ${ }^{*}$ & ${ }^{*}$ & NS & ** & NS \\
\hline \multicolumn{11}{|l|}{ Supplements (B): } \\
\hline $0.0(\mathrm{~B} 1)$ & $2223^{a}$ & 58.00 & $383^{a}$ & 13.33 & $354^{\mathrm{a}}$ & $97.3^{\mathrm{ab}}$ & $75.8^{\mathrm{ab}}$ & 6.83 & $14.7^{\mathrm{ab}}$ & 62.37 \\
\hline $0.1 \mathrm{Se}(\mathrm{B} 2)$ & $2153^{a}$ & 58.85 & $372^{\mathrm{a}}$ & 16.83 & $325^{\mathrm{ab}}$ & $115^{\mathrm{a}}$ & $88.3^{\mathrm{a}}$ & 9.33 & $17.5^{\mathrm{a}}$ & 63.13 \\
\hline 1.1 .0 glutamine (B3) & $1897^{b}$ & 57.50 & $321^{b}$ & 13.00 & $295^{\mathrm{b}}$ & $82.2^{\mathrm{b}}$ & $63.3^{\mathrm{b}}$ & 5.83 & $13.0^{\mathrm{b}}$ & 61.80 \\
\hline SEM & 41 & 0.96 & 9.3 & 1.36 & 13 & 8.07 & 6.22 & 1.19 & 1.39 & 0.93 \\
\hline Significance & ** & NS & ** & NS & * & * & * & NS & NS & NS \\
\hline \multicolumn{11}{|l|}{ AB Interaction: } \\
\hline $\mathrm{A} 1 \mathrm{~B} 1=\mathrm{R} 1$ & 2318 & 59.40 & 398 & 11.67 & 345 & 105.0 & 83.3 & 6.66 & 15.0 & 63.90 \\
\hline $\mathrm{A} 1 \mathrm{~B} 2=\mathrm{R} 2$ & 2263 & 57.50 & 393 & 20.0 & 352 & 135.0 & 102 & 11.7 & 21.7 & 63.47 \\
\hline $\mathrm{A} 1 \mathrm{~B} 3=\mathrm{R} 3$ & 2053 & 58.3 & 345 & 16.0 & 302 & 96.0 & 73.3 & 6.66 & 16.0 & 62.70 \\
\hline $\mathrm{A} 2 \mathrm{~B} 1=\mathrm{R} 4$ & 2128 & 56.60 & 367 & 15.0 & 363 & 89.7 & 68.3 & 7.0 & 14.3 & 60.83 \\
\hline $\mathrm{A} 2 \mathrm{~B} 2=\mathrm{R} 5$ & 2042 & 58.20 & 350 & 13.67 & 298 & 95.3 & 75.0 & 7.0 & 13.3 & 62.80 \\
\hline $\mathrm{A} 2 \mathrm{~B} 3=\mathrm{R} 6$ & 1740 & 56.97 & 297 & 10.00 & 288 & 68.3 & 53.3 & 5.0 & 10.0 & 60.90 \\
\hline SEM & 57.5 & 1.36 & 13 & 1.925 & 18.6 & 11.42 & 8.79 & 1.68 & 1.97 & 1.32 \\
\hline Significance & NS & NS & NS & NS & NS & NS & NS & NS & NS & NS \\
\hline
\end{tabular}

$a-b$ : For each of the main effects, means within the same column with different superscripts differ significantly ( $P \leq 0.05)$. SEM=standard error of means.

100. ${ }^{\star}$ Total dressing percentage $=(\text { carcass yield }+ \text { edible organs/live body weight })^{\star} 100 \mathrm{SEM}=$ standard error of means. 